\title{
Nutrient Input via Incident Rainfall in a Eucalyptus dunnii Stand in the Pampa biome
}

\author{
Grasiele Dick $^{1}$, Mauro Valdir Schumacher ${ }^{1}$, Dione Richer Momolli ${ }^{1}$, \\ Márcio Viera ${ }^{1}$
}

${ }^{1}$ Universidade Federal de Santa Maria - UFSM, Santa Maria/RS, Brasil

\begin{abstract}
We evaluated the nutrient input via incident rainfall in a Eucalyptus dunnii stand in the Brazilian Pampa biome. During the two-year study, we analyzed nutrient concentrations in incident rainfall $(\mathrm{P})$, throughfall via drip $(\mathrm{Pi})$, and stemflow (Et). Ion concentrations $\left(\mathrm{NO}_{2}{ }^{-}, \mathrm{NO}_{3}{ }^{-}, \mathrm{PO}_{4}{ }^{3-}, \mathrm{SO}_{4}{ }^{2-}, \mathrm{Cl}^{-}\right.$, $\mathrm{K}^{+}, \mathrm{Ca}^{2+}$, and $\mathrm{Mg}^{2+}$ ) were determined from the aqueous solution, and based on the water volume, the quantity per hectare $\left(\mathrm{kg} \mathrm{ha}^{-1}\right)$ was estimated for each element. Statistical differences observed by ANOVA and separation of means contrasts were subjected to Tukey's test (5\%), adopting a completely randomized design. Higher concentrations of $\mathrm{SO}_{4}^{2-}$ in $\mathrm{P} ; \mathrm{NO}_{3}-$ in $\mathrm{Pi}$ solution, and $\mathrm{K}^{+}, \mathrm{Ca}^{2+}, \mathrm{Mg}^{2+}$, and $\mathrm{Cl}^{-}$in Et were observed. Greater amounts of nutrients such as $\mathrm{Cl}^{-}, \mathrm{K}^{+}, \mathrm{Ca}^{2+}$, and $\mathrm{SO}_{4}^{2}$ were incorporated via $\mathrm{Pi}$.
\end{abstract}

Keywords: forest hydrology, forest nutrition, geochemical cycling. 


\section{INTRODUCTION}

The productivity of commercial tree plantations is influenced by the supply of minerals dissolved in water and those introduced via atmospheric deposition. Nutrient input through rainfall is important to maintain the productive capacity of soils where eucalyptus silviculture is practiced (Schumacher \& Viera, 2015).

Water passing through the canopy of trees removes large amounts of atmospheric particles and aerosols, which are deposited on the surface of plant tissues (Waring \& Schlesinger, 1985). These nutrient flows ensure forest productivity and can be boosted by nutrient inputs through rainfall, which comprises an important stage of geochemical cycling (Ashagrie \& Zech, 2010).

Trees influence the nutrient return to the soil, changing the amount and chemical composition of non-intercepted rainfall (Carnol \& Bazgir, 2013). Tree canopies influence atmospheric deposition of nutrients, contributing to the redistribution of rainfall, changing the $\mathrm{pH}$ and ion concentrations, and washing the dry deposits on the canopy and leaching elements from the vegetal tissues (Shen et al., 2013).

The concentration of nutrients in incident rainfall increases after contact with the crowns of forest plantations. This pattern was verified in Eucalyptus dunnii (Corrêa, 2011), Eucalyptus grandis (Balieiro et al., 2007; Laclau et al., 2010), Eucalyptus sp. (Laclau et al., 2003), Eucalyptus urophylla $\times$ Eucalyptus grandis (Laclau et al., 2010), and Eucalyptus globulus (Ashagrie \& Zech, 2010).

Vegetation cover in forest plantations has a prominent function in water balance, and the type of vegetation also influences the uptake of water and nutrients (Diniz et al., 2013). Vegetation cover varies over time, in response to fluctuations in precipitation quality, variations in the availability of aerosols and vegetation exudates, and precipitation intensity (Walling, 1980).

As silviculture branches out into new areas, especially in degraded areas with low productive potential, the evaluation and understanding of nutrient inputs due to incident rainfall may aid in the efficient management of fertilization, leading to the conservation of natural resources. The objective of this study was to evaluate the nutrient input through incident rainfall in a Eucalyptus dunnii stand, established in the Pampa biome of Brazil.

\section{MATERIAL AND METHODS}

\subsection{Study site characterization}

The study was conducted in a Eucalyptus dunnii stand located in Alegrete, Rio Grande do Sul, Brazil, under the central geographic coordinates of $29^{\circ} 47^{\prime} \mathrm{S}$ and $55^{\circ} 17^{\prime} \mathrm{W}$. According to the climatic classification of Köppen, the climate of this region is type $\mathrm{Cfa}$, with high temperatures in the summer season (Alvares et al., 2014). The annual average temperature is $18.6^{\circ} \mathrm{C}$ and the average annual rainfall is $1574 \mathrm{~mm}$. The soil, which presents low fertility, is classified as typical Distrophic Red Argisol (EMBRAPA, 2013), with sandy texture, ranging from sandy-loam to sandy-loam.

Soil preparation was carried out with subsoiling at an average depth of $60 \mathrm{~cm}$ and seedling planting at $2.0 \mathrm{~m} \times 3.5 \mathrm{~m}$ spacing. Planting was carried out manually during January 2009. The following cultivations were carried out in the planting: application of $300 \mathrm{~kg} \mathrm{ha}^{-1}$ of $\mathrm{N}-\mathrm{P}_{2} \mathrm{O}_{5}-\mathrm{K}_{2} \mathrm{O}$, in the proportion 06-30-06 + 0.6\% of B, 30 days before planting. The second application of fertilizer was at 90 days after planting; $140 \mathrm{~kg} \mathrm{ha}^{-1}$ of $\mathrm{N}-\mathrm{P}_{2} \mathrm{O}_{5}-\mathrm{K}_{2} \mathrm{O}$ was applied in the proportion $22-05-20+0.2 \%$ of $\mathrm{B}+0.4 \%$ of $\mathrm{Zn}$. The third application of fertilizer was 270 days after planting, with $140 \mathrm{~kg} \mathrm{ha}^{-1}$ of N- $\mathrm{P}_{2} \mathrm{O}_{5}-\mathrm{K}_{2} \mathrm{O}$, at the proportion $22-00-18+1.0 \%$ of $S+0.3 \%$ of $\mathrm{B}$. In addition to chemical fertilizers applied mechanically in the interline, chemical weeding, mechanical weeding, ant-fighting cutters and firebreak maintenance were also carried out in the stand.

The trees were 48 months old at the beginning of the experiment. Their mean diameter at breast height (DBH) was $11.9 \mathrm{~cm}$, mean height of $13.8 \mathrm{~m}$, leaf area index (LAI) of $2.78 \mathrm{~m}^{2}$, basal area (G) of $14.0 \mathrm{~m}^{2} \mathrm{ha}^{-1}$, number of trees $(\mathrm{N})$ of 1143 and volume of $124.3 \mathrm{~m}^{3} \mathrm{ha}^{-1}$.

\subsection{Water sampling}

Chemical analysis of rainfall water was initiated in January 2012 and ended in December 2013. Incident rainfall $(\mathrm{P})$, throughfall $(\mathrm{Pi})$, and stemflow $(\mathrm{Et})$ were evaluated (Figure 1).

Incident rainfall was determined using three rain gauges installed in an area adjacent to the eucalyptus stand. Throughfall was determined with the installation of twelve rain gauges. Both the collectors for the quantification of water volume of incident rainfall and 
for throughfall, had a diameter of $20 \mathrm{~cm}$. However, for water sampling for chemical analysis, collectors with a diameter of $15 \mathrm{~cm}$ were used.

The stemflow (Et) was measured using twelve collectors. The Et collectors were made of a $60 \mathrm{~L}$ stocking hose and a collecting container, attached to the trunk, at a height of $150 \mathrm{~cm}$ from the ground, using polyurethane foam and silicone glue.

Samples were collected biweekly. In each collector, the precipitated volume was measured. During collection, an aliquot was removed for chemical analysis. In the laboratory, the $\mathrm{pH}$ values were determined with a pH meter (Metrohm 827 pH LAB). After filtration

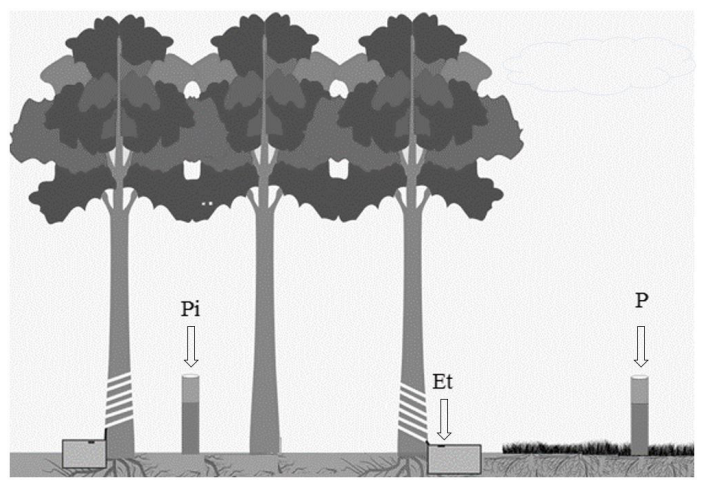

Figure 1. Distribution scheme for incident rainfall $(\mathrm{P})$, throughfall $(\mathrm{Pi})$ and stemflow $(\mathrm{Et})$ collectors in Eucalyptus dunnii stand, Alegrete/RS. using a $0.45-\mu \mathrm{m}$ filter, the $\mathrm{NO}_{2}^{-}, \mathrm{NO}_{3}^{-}, \mathrm{PO}_{4}^{3-}, \mathrm{SO}_{4}^{2-}, \mathrm{Cl}^{-}$, $\mathrm{K}^{+}, \mathrm{Ca}^{2+}$, and $\mathrm{Mg}^{2+}$ ions were determined by means of ion chromatography (Metrohm 861 Advanced Compac IC), according to the methodology proposed by APHA et al. (1998).

The normal distribution and homogeneity of variances were verified by Shapiro-Wilk and Bartlett tests, respectively. To meet these assumptions, there was a need for logarithmic transformations of the individual concentrations. Tukey's test and Student's $t$-test were applied after ANOVA, both with a 5\% probability of error, to separate the means contrasts. In the statistical analysis, we adopted a completely randomized design with different numbers of repeitions, where the treatments were incident rainfall, throughfall and stemflow, and each monthly composite sample corresponded to one repetition. The analyses were performed with the assistance of the program Assistat version 7.7 (Silva \& Azevedo, 2002).

\section{RESULTS AND DISCUSSION}

\subsection{Distribution of incident rainfall}

In relation to the evaluated periods, it was observed that there were higher values of throughfall and stemflow in 2013 (Table 1). The difference of $502.52 \mathrm{~mm}$ incident rainfall between the two years was due to the influence of the "La Niña" phenomenon, which occurred in Brazil

Table 1. Mean values \pm standard deviation in incident rainfall $(\mathrm{P})$, throughfall $(\mathrm{Pi})$ and stemflow $(\mathrm{Et})$ in $2012\left({ }_{12}\right)$ and $2013\left({ }_{13}\right)$, in a Eucalyptus dunnii stand, Alegrete/RS.

\begin{tabular}{ccccccc}
\multirow{2}{*}{ Month } & $\mathbf{P}_{\mathbf{1 2}}$ & $\mathbf{P}_{13}$ & $\mathbf{P i}_{\mathbf{1 2}}$ & $\mathbf{P i}_{\mathbf{1 3}}$ & $\mathbf{E t}_{\mathbf{1 2}}$ & $\mathbf{E t}_{\mathbf{1 3}}$ \\
\cline { 2 - 7 } Jan & $6.37 \pm 0.45 \mathrm{~b}^{*}$ & $102.39 \pm 2.34 \mathrm{a}$ & $5.95 \pm 0.33 \mathrm{~b}$ & $88.64 \pm 1.15 \mathrm{a}$ & $0.02 \pm 0.001 \mathrm{~b}$ & $0.69 \pm 0.09 \mathrm{a}$ \\
\hline Feb & $106.63 \pm 0.90 \mathrm{~b}$ & $162.76 \pm 1.32 \mathrm{a}$ & $93.95 \pm 4.91 \mathrm{~b}$ & $148.57 \pm 7.69 \mathrm{a}$ & $0.49 \pm 0.17 \mathrm{a}$ & $0.62 \pm 0.44 \mathrm{a}$ \\
\hline Mar & $0 \mathrm{~b}$ & $180.59 \pm 0.80 \mathrm{a}$ & $0 \mathrm{~b}$ & $170.75 \pm 2.31 \mathrm{a}$ & $0 \mathrm{~b}$ & $2.37 \pm 0.48 \mathrm{a}$ \\
Apr & $106.71 \pm 16.54 \mathrm{a}$ & $131.14 \pm 0.63 \mathrm{a}$ & $102.92 \pm 6.98 \mathrm{a}$ & $113.69 \pm 1.31 \mathrm{a}$ & $0.96 \pm 0.29 \mathrm{a}$ & $1.24 \pm 0.25 \mathrm{a}$ \\
\hline May & $31.51 \pm 0.45 \mathrm{~b}$ & $194.49 \pm 0.63 \mathrm{a}$ & $26.77 \pm 2.09 \mathrm{~b}$ & $181.49 \pm 2.87 \mathrm{a}$ & $0.23 \pm 0.06 \mathrm{~b}$ & $0.82 \pm 0.23 \mathrm{a}$ \\
\hline Jun & $57.45 \pm 0.67 \mathrm{~b}$ & $71.09 \pm 0.48 \mathrm{a}$ & $53.05 \pm 3.39 \mathrm{a}$ & $61.38 \pm 2.34 \mathrm{a}$ & $0.48 \pm 0.23 \mathrm{a}$ & $1.02 \pm 0.36 \mathrm{a}$ \\
\hline Jul & $82.44 \pm 4.50 \mathrm{~b}$ & $131.15 \pm 1.80 \mathrm{a}$ & $68.77 \pm 2.57 \mathrm{~b}$ & $121.35 \pm 7.56 \mathrm{a}$ & $0.62 \pm 0.27 \mathrm{a}$ & $1.32 \pm 0.41 \mathrm{a}$ \\
Aug & $147.85 \pm 0.96 \mathrm{a}$ & $58.09 \pm 0.67 \mathrm{~b}$ & $142.89 \pm 2.80 \mathrm{a}$ & $48.22 \pm 4.50 \mathrm{~b}$ & $1.48 \pm 0.58 \mathrm{a}$ & $0.35 \pm 0.14 \mathrm{~b}$ \\
\hline Sep & $72.15 \pm 0.18 \mathrm{a}$ & $34.85 \pm 1.57 \mathrm{~b}$ & $63.45 \pm 0.52 \mathrm{a}$ & $29.55 \pm 2.41 \mathrm{~b}$ & $0.61 \pm 0.10 \mathrm{a}$ & $0.18 \pm 0.06 \mathrm{~b}$ \\
\hline Oct & $180.42 \pm 2.83 \mathrm{a}$ & $89.60 \pm 2.92 \mathrm{~b}$ & $163.87 \pm 0.60 \mathrm{a}$ & $83.43 \pm 3.63 \mathrm{~b}$ & $2.56 \pm 0.04 \mathrm{a}$ & $3.23 \pm 0.84 \mathrm{a}$ \\
\hline Nov & $12.57 \pm 0.42 \mathrm{~b}$ & $456.77 \pm 10.80 \mathrm{a}$ & $9.96 \pm 0.21 \mathrm{~b}$ & $427.62 \pm 11.43 \mathrm{a}$ & $0.05 \pm 0.03 \mathrm{~b}$ & $8.79 \pm 1.43 \mathrm{a}$ \\
Dec & $330.33 \pm 1.50 \mathrm{a}$ & $24.03 \pm 1.35 \mathrm{~b}$ & $301.71 \pm 7.80 \mathrm{a}$ & $22.77 \pm 1.54 \mathrm{a}$ & $2.90 \pm 0.18 \mathrm{a}$ & $0.35 \pm 0.07 \mathrm{~b}$ \\
\hline Total & $\mathbf{1 1 3 4 . 4 3}$ & $\mathbf{1 6 3 6 . 9 5}$ & $\mathbf{1 0 3 3 . 2 9}$ & $\mathbf{1 4 9 7 . 4 6}$ & $\mathbf{1 0 . 4 0}$ & $\mathbf{2 0 . 9 8}$ \\
\hline
\end{tabular}

*Values followed by the same letter in the row for 2012 and 2013, considering the different precipitation flows, do not differ statistically by Student's $t$-test, at $5 \%$ error probability level. 
from December 2011 to March 2012 (Melo, 2011), causing below-average rainfall for the state of Rio Grande do Sul. However, in terms of expectations based on the precipitation history of the region, lower volumes of incident rainfall and throughfall were recorded in March 2012 and December 2013, whereas larger volumes of incident rainfall, throughfall and stemflow occurred in December 2012 and November 2013.

The incident rainfall in 2012 was distributed in $91.08 \%$ via throughfall and $0.91 \%$ via stemflow. In $2013,91.48 \%$ of incident rainfall was quantified in throughfall and $1.28 \%$ in stemflow. The highest volumes of throughfall were associated with the leaf area index of the stands, as the canopy cover allowed greater passage of rainwater through the canopies. According to Whitehead \& Beadle (2004), low leaf area index and seasonal dynamics are two of the mechanisms that facilitate the passage of precipitation through the canopy to alleviate water deficits in the soil. These results also showed that larger volumes of aqueous solution flowing through the trunk are directly influenced by the precipitation intensity.

In the same study area, Corrêa (2011) also evaluated incident rainfall. However, the monitoring period began at 36 months and ended at 48 months. The author observed a higher volume of incident rainfall, registering $1586 \mathrm{~mm}$ year $^{-1}$. Of this total, 93\% was collected inside the stand, where $98 \%$ was from throughfall and $2 \%$ from stemflow. These results, obtained at the study site over a different time scale, revealed similarities in the distribution of throughfall, with less interception of rainwater by the canopy when the trees are younger (Chang, 2006).

A similar pattern of incident rainfall distribution was also found by Laclau et al. (2003), in Eucalyptus sp. up to 72 months of age, planted in the Congo. During the rainy season, which covers the months from October to May, the authors observed that $91 \%$ of the total effective precipitation corresponded to throughfall and $1.9 \%$ to stemflow.

In relation to stemflow, in a study in the Atlantic Forest, considering different levels of ecological succession in native forest fragments, Diniz et al. (2013) found that less than $0.3 \%$ of the water flowed through tree trunks; the authors found that volumes of incident rainfall, throughfall, and interception were similar between the three stages evaluated.

\subsection{Nutrient concentration in incident rainfall, throughfall and stemflow}

After the water crossed the canopy of the trees, there was an increase in the $\mathrm{pH}$ values in 2013 and in the concentration of most of the nutrients, in the two evaluated periods. The contribution of ions contained in the water from throughfall $(\mathrm{Pi})$, relative to the incident rainfall $(\mathrm{P})$, tended to enrich the accumulated amounts of ions, except for $\mathrm{PO}_{4}^{3-}$ and $\mathrm{NO}_{2}{ }^{-}$in 2013 (Table 2).

During the two years, significant differences were observed in the concentrations of cations and anions, mainly for nitrate $\left(\mathrm{NO}_{3}{ }^{-}\right)$in the internal precipitation and for $\mathrm{PO}_{4}^{3-}, \mathrm{K}^{+}, \mathrm{Mg}^{2+}$, and $\mathrm{Cl}^{-}$that are present in higher concentrations in the stemflow solution. It was

Table 2. Annual $\mathrm{pH}$ values and concentrations (mean \pm standard deviation) of ions present in solution in incident rainfall (P), throughfall (Pi) and stemflow (Et) in $2012\left(_{12}\right)$ and $2013\left({ }_{13}\right)$, in a Eucalyptus dunnii stand, Alegrete/RS.

\begin{tabular}{|c|c|c|c|c|c|c|}
\hline \multirow{2}{*}{ pH } & $\mathbf{P}_{12}$ & $P_{13}$ & $\mathbf{P i}_{12}$ & $\mathbf{P i}_{13}$ & $\mathrm{Et}_{12}$ & $\mathrm{Et}_{13}$ \\
\hline & $5.44 \pm 0.71 \mathrm{~A}^{\star}$ & $4.31 \pm 0.37 b^{* *}$ & $5.78 \pm 0.47 \mathrm{~A}$ & $5.00 \pm 0.44 a$ & $5.30 \pm 0.61 \mathrm{~A}$ & $5.30 \pm 0.42 \mathrm{a}$ \\
\hline Ions & \multicolumn{6}{|c|}{$\mathrm{mg} \mathrm{L}^{-1}$} \\
\hline $\mathrm{NO}_{2}^{-}$ & $0.02 \pm 0.01 \mathrm{~B}$ & $0.02 \pm 0.01 \mathrm{a}$ & $0.09 \pm 0.09 \mathrm{~A}$ & $0.01 \pm 0.01 \mathrm{a}$ & $0.31 \pm 0.75 \mathrm{~A}$ & $0.02 \pm 0.02 \mathrm{a}$ \\
\hline $\mathrm{NO}_{3}^{-}$ & $0.16 \pm 0.20 \mathrm{~B}$ & $0.08 \pm 0.06 b$ & $0.47 \pm 0.45 \mathrm{~A}$ & $0.23 \pm 0.19 a$ & $0.25 \pm 0.29 \mathrm{~B}$ & $0.02 \pm 0.03 b$ \\
\hline $\mathrm{PO}_{4}^{3-}$ & $0.07 \pm 0.05 \mathrm{~B}$ & $0.11 \pm 0.00 \mathrm{a}$ & $0.05 \pm 0.05 \mathrm{~B}$ & $0.02 \pm 0.00 \mathrm{~b}$ & $0.14 \pm 0.30 \mathrm{~A}$ & $0.07 \pm 0.12 \mathrm{a}$ \\
\hline $\mathrm{K}^{+}$ & $0.41 \pm 0.30 \mathrm{C}$ & $0.17 \pm 0.09 \mathrm{c}$ & $2.07 \pm 1.56 \mathrm{~B}$ & $0.96 \pm 0.34 b$ & $11.65 \pm 12.19 \mathrm{~A}$ & $10.64 \pm 7.37 \mathrm{a}$ \\
\hline $\mathrm{Ca}^{2+}$ & $1.78 \pm 1.69 \mathrm{~B}$ & $0.60 \pm 0.43 b$ & $2.26 \pm 1.68 \mathrm{~A}$ & $1.22 \pm 0.48 \mathrm{a}$ & $2.08 \pm 1.54 \mathrm{~A}$ & $2.05 \pm 1.45 \mathrm{a}$ \\
\hline $\mathrm{Mg}^{2+}$ & $0.14 \pm 0.12 \mathrm{~B}$ & $0.11 \pm 0.14 \mathrm{~b}$ & $0.50 \pm 0.37 \mathrm{~B}$ & $0.32 \pm 0.27 \mathrm{~b}$ & $2.33 \pm 2.30 \mathrm{~A}$ & $2.42 \pm 1.88 \mathrm{a}$ \\
\hline $\mathrm{SO}_{4}^{2-}$ & $0.97 \pm 0.55 \mathrm{~A}$ & $0.53 \pm 0.35 a$ & $1.39 \pm 1.12 \mathrm{~A}$ & $0.88 \pm 0.58 \mathrm{a}$ & $0.92 \pm 1.19 \mathrm{~A}$ & $0.46 \pm 0.37 \mathrm{a}$ \\
\hline $\mathrm{Cl}^{-}$ & $1.92 \pm 2.26 \mathrm{~B}$ & $0.51 \pm 0.33 c$ & $2.63 \pm 2.22 \mathrm{~B}$ & $1.84 \pm 0.87 \mathrm{~b}$ & $10.62 \pm 12.47 \mathrm{~A}$ & $8.31 \pm 7.60 \mathrm{a}$ \\
\hline
\end{tabular}

*Values followed by the same capital letter in the row do not differ statistically in 2012 by Tukey's test, at a 5\% error probability level;

${ }^{*}$ Values followed by the same lowercase letter in the line did not differ statistically in 2013 by Tukey's test, at $5 \%$ error probability. 
possible to verify that the concentrations of all elements increased after the water crossed the canopy and flowed through the trunk. Due to the action of the crown of trees in leaching of metabolites next to the stemflow, the concentration of $\mathrm{K}^{+}$increased by $280 \%$ in 2012 and by $625 \%$ in 2013 . It was also found that, in 2013 , the aqueous solution of the stemflow presented higher $\mathrm{pH}$ values than that of incident rainfall and throughfall. Corrêa (2011) analyzed a Eucalyptus dunnii stand at 2.5 years, and found increases of $600 \%$ of $\mathrm{K}^{+}, 295 \%$ of $\mathrm{Cl}^{-}, 125 \%$ of $\mathrm{Mg}^{2+}, 43.67 \%$ of $\mathrm{Ca}^{2+}$, and $10 \%$ of $\mathrm{PO}_{4}^{3-}$, respectively, after passing through the canopy of the eucalyptus stand.

The order of nutrient input was $\mathrm{Cl}^{-}>\mathrm{Ca}^{2+}>\mathrm{SO}_{4}^{2-}>$ $\mathrm{K}^{+}>\mathrm{NO}_{3}^{-}>\mathrm{Mg}^{2+}>\mathrm{NO}_{2}{ }^{-}>\mathrm{PO}_{4}{ }^{3-}$ for incident rainfall in 2012. In 2013, the order followed the sequence $\mathrm{SO}_{4}{ }^{2-}>\mathrm{Cl}^{-}>\mathrm{Ca}^{2+}>\mathrm{K}^{+}>\mathrm{Mg}^{2+}=\mathrm{PO}_{4}{ }^{3-}>\mathrm{NO}_{3}{ }^{-}>\mathrm{NO}_{2}$. For throughfall in 2012, the sequence $\mathrm{Cl}^{-}>\mathrm{Ca}^{2+}>\mathrm{K}^{+}>$ $\mathrm{SO}_{4}^{-}>\mathrm{Mg}^{2+}>\mathrm{NO}_{3}^{-}>\mathrm{NO}_{2}^{-}>\mathrm{PO}_{4}^{3-}$ was observed. In 2013, practically the same sequence was maintained, except for the order $\mathrm{PO}_{4}{ }^{3-}>\mathrm{NO}_{2}$. For stemflow, in 2012 , the sequence $\mathrm{K}^{+}>\mathrm{Cl}^{-}>\mathrm{Mg}^{2+}>\mathrm{Ca}^{2+}>\mathrm{SO}_{4}{ }^{2-}>$ $\mathrm{NO}_{2}^{-}>\mathrm{NO}_{3}^{-}>\mathrm{PO}_{4}^{3-}$ was verified. In 2013, stemflow followed the sequence $\mathrm{K}^{+}>\mathrm{Cl}^{-}>\mathrm{Mg}^{2+}>\mathrm{Ca}^{2+}>\mathrm{SO}_{4}{ }^{2-}>$ $\mathrm{PO}_{4}^{3-}>\mathrm{NO}_{2}^{-}=\mathrm{NO}_{3}^{-}$.

With regard to the seasonal contribution of ions (Figure 2), it can be observed that the distribution presented a varied fluctuation, where the highest concentrations of elements occurred in the months
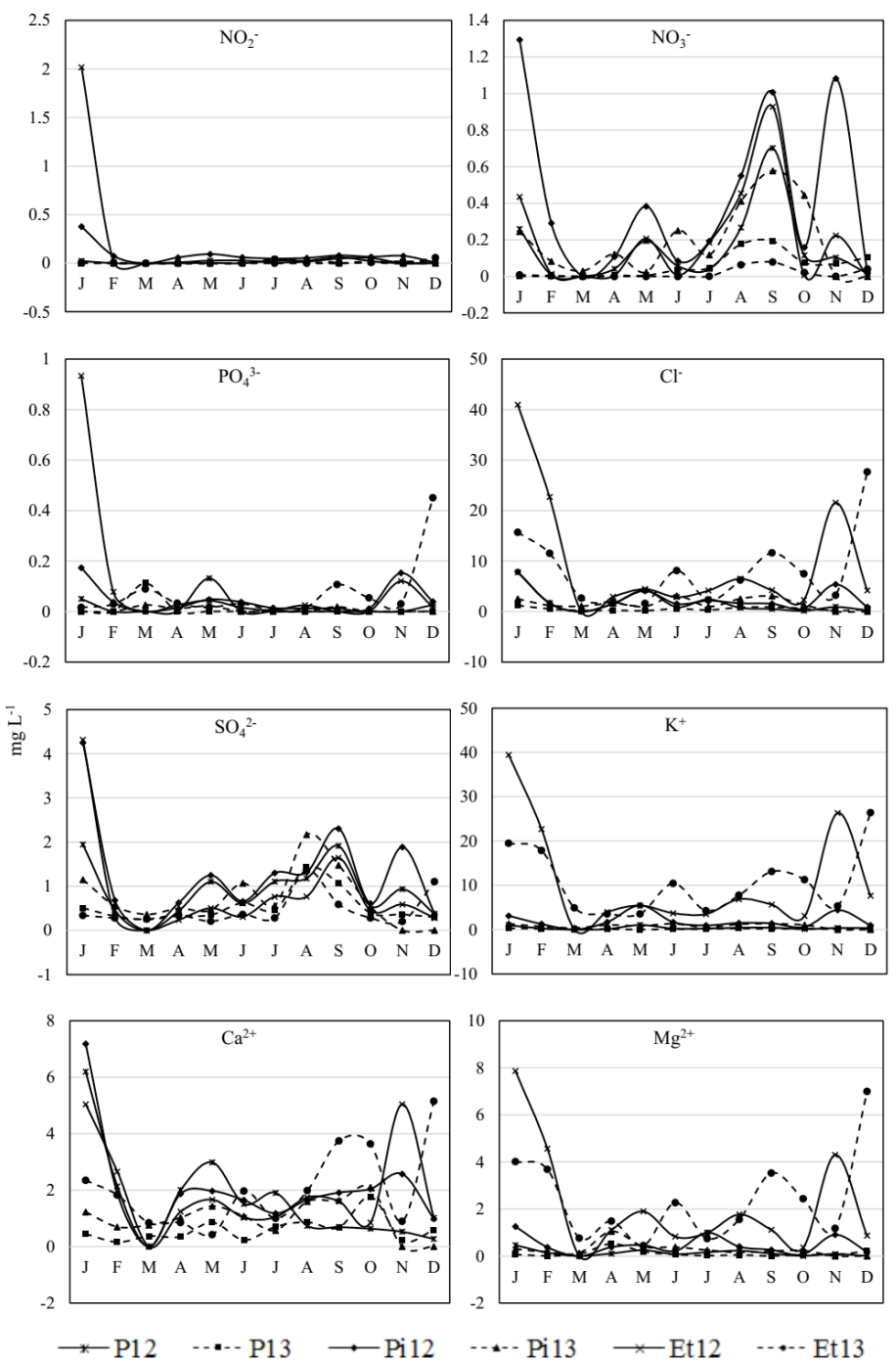

Figure 2. Seasonality of nutrient concentrations in solution in incident rainfall (P), throughfall (Pi) and stemflow (Et) in $2012\left({ }_{12}\right)$ and $2013\left({ }_{13}\right)$, in a Eucalyptus dunnii stand, Alegrete/RS. 
when there was less rainfall. Paramee et al. (2005) also verified that the pattern and amount of moisture deposition were strongly influenced by the precipitated volume. The concentration of nutrients is inversely proportional to the amount of water; the lower the precipitation volume, the lower the nutrient dilution in water and, consequently, the higher the concentrations (Chang, 2006; Laclau et al., 2003).

Higher concentrations of $\mathrm{SO}_{4}^{2-}, \mathrm{Ca}^{2+}$, and $\mathrm{Cl}^{-}$in the aqueous solution of incident rainfall were also observed by Corrêa (2011) in the same study area. Heartsill-Scalley et al. (2007) in a subtropical forest and Laclau et al. (2003), in a study of Eucalyptus sp., among other studies (Shen et al., 2013; Wang et al., 2004; Bellot \& Escarre, 1991) also showed higher concentrations of these ions.

The presence of high $\mathrm{SO}_{4}^{2-}$ concentrations in the chemical composition of incident rainfall is indicated as one of the consequences of anthropogenic emissions that contribute to the increase in atmospheric pollution resulting from burning, industrial activity, and combustion of petroleum fuels, as reported by Garten et al. (1988), Singer et al. (1996), and Armbruster et al. (2003). The quality of the incident rainfall is also influenced by the deposition of particles, which are derived from vegetation biomass fires and enrich the precipitation with $\mathrm{SO}_{4}^{2-}, \mathrm{Ca}^{2+}, \mathrm{Cl}^{-}$, and $\mathrm{NO}_{3}^{-}$(Laclau et al., 2003). This practice is common in the field areas of the Pampa biome, used as an alternative for pasture renewal and elimination of invasive plants (Verdum et al., 2014).

The accumulation of dust and ash on the canopy, which are carried after the leaf intercepts water, may have led to the increase in ion concentrations, as can be observed in the present and previous studies (Shen et al., 2013; Heartsill-Scalley et al., 2007; Balestrini et al., 2007; Dezzeo \& Chacón, 2006). After interaction with the canopy, all ions in the throughfall solution were enriched, with higher concentrations of $\mathrm{Cl}^{-}, \mathrm{K}^{+}, \mathrm{SO}_{4}^{2-}$, and $\mathrm{Ca}^{2+}$. These findings were consistent with those observed in the native forests of Venezuela (Dezzeo \& Chacón, 2006), in Quercus stands (Rodà et al., 1990), and in the native forests of India (Prakasa Rao et al., 1995).

After interaction with the canopy, precipitation is susceptible to leaching potassium from plant tissues. Potassium does not participate in the structural constitution of organic compounds, and therefore, it is found in its ionic form inside the cells, acting in the control of stomatal opening and closure (Epstein \& Bloom, 2006). Calcium is closely associated with the cell wall of tissues (Taiz \& Zeiger, 2013). Therefore, high concentrations of this nutrient in the solution of the precipitation can be traced to the drift of limestone particles, applied in crops near the study area.

In the solution of stemflow, except for $\mathrm{SO}_{4}{ }^{2-}$ and $\mathrm{NO}_{3}^{-}$, higher concentrations of ions, mainly $\mathrm{K}^{+}$, were registered relative to incident rainfall and throughfall. In a Eucalyptus sp. stand, Laclau et al. (2003) also verified a reduction in the nitrate content after stemflow, to the detriment of the cationic changes resulting from the interaction of this element with the leaves. According to Armbruster et al. (2003), the reduction in sulfate content after stemflow occurs as a result of the interaction of this element with the organic acids of the plant tissue. Nitrate can also be volatilized after interaction with stem water, which makes the solution of stemflow less acidic relative to incident rainfall and throughfall.

\subsection{Nutrient input via incident rainfall, throughfall and stemflow}

After measuring the quantities of ions from incident rainfall on the Eucalyptus dunnii stand (Table 3), a greater contribution of $\mathrm{Ca}^{2+}$ and $\mathrm{Cl}^{-}$was observed in the incident rainfall and throughfall. In stemflow, the highest contribution was from $\mathrm{K}^{+}$during the two evaluation periods.

The higher nutrient quantities observed in 2012 are a reflection of their higher concentrations, which occurred due to lower rainfall volume and less dilution of nutrients. Enrichment of rainwater after passing through the canopy was responsible for greater nutrient input into the stand, thus highlighting the importance of the geochemical cycle in nutritional dynamics of eucalyptus culture.

The elements incorporated in the largest quantities were $\mathrm{Ca}^{2+}, \mathrm{Cl}, \mathrm{SO}_{4}^{2-}$, and $\mathrm{K}^{+}$, a situation also observed by Heartsill-Scalley et al. (2007). This results from the accumulation of dry and wet deposition on the canopy, carried through leaching and foliar washing. Potassium was also found to be higher in stemflow solution.

The addition of potassium to the aqueous solution, after interaction with the canopy, also occurred in an Acacia mangium stand in China, where precipitation measures 2172.7 mm year $^{-1}$ (Shen et al., 2013); the authors 
Table 3. Annual mean quantities $\left(\mathrm{kg} \mathrm{ha}^{-1}\right)$ of ions present in solution of incident rainfall $(\mathrm{P})$, throughfall $(\mathrm{Pi})$ and stemflow (Et) in $2012\left({ }_{12}\right)$ and $2013\left({ }_{13}\right)$, in a Eucalyptus dunnii stand, Alegrete/RS.

\begin{tabular}{ccccccc}
\hline Ions & $\mathbf{P}_{12}$ & $\mathbf{P}_{13}$ & $\mathbf{P i}_{\mathbf{1 2}}$ & $\mathbf{P i}_{13}$ & $\mathbf{E t}_{12}$ & $\mathbf{E t}_{\mathbf{1 3}}$ \\
\hline $\mathrm{NO}^{2-}$ & $0.20 \mathrm{a}$ & $0.08 \mathrm{~b}$ & $0.47 \mathrm{a}$ & $0.07 \mathrm{~b}$ & $0.002 \mathrm{a}$ & $2 \times 10^{-4} \mathrm{~b}$ \\
\hline $\mathrm{NO}^{3-}$ & $1.36 \mathrm{a}$ & $0.50 \mathrm{~b}$ & $2.35 \mathrm{a}$ & $1.25 \mathrm{~b}$ & $0.012 \mathrm{a}$ & $7 \times 10^{-4} \mathrm{~b}$ \\
\hline $\mathrm{PO}_{4}^{3-}$ & $0.10 \mathrm{a}$ & $0.15 \mathrm{a}$ & $0.26 \mathrm{a}$ & $0.12 \mathrm{~b}$ & $0.002 \mathrm{~b}$ & $0.005 \mathrm{a}$ \\
\hline $\mathrm{K}^{+}$ & $3.33 \mathrm{a}$ & $1.84 \mathrm{~b}$ & $13.90 \mathrm{a}$ & $7.74 \mathrm{~b}$ & $0.631 \mathrm{a}$ & $0.970 \mathrm{a}$ \\
\hline $\mathrm{Ca}^{2+}$ & $10.84 \mathrm{a}$ & $8.00 \mathrm{~b}$ & $16.04 \mathrm{a}$ & $11.87 \mathrm{a}$ & $0.122 \mathrm{a}$ & $0.225 \mathrm{~b}$ \\
\hline $\mathrm{Mg}^{2+}$ & $0.83 \mathrm{a}$ & $1.94 \mathrm{~b}$ & $2.68 \mathrm{a}$ & $3.70 \mathrm{a}$ & $0.097 \mathrm{~b}$ & $0.183 \mathrm{a}$ \\
\hline $\mathrm{SO}_{4}^{2-}$ & $7.49 \mathrm{a}$ & $6.04 \mathrm{a}$ & $8.05 \mathrm{a}$ & $5.96 \mathrm{a}$ & $0.051 \mathrm{a}$ & $0.045 \mathrm{a}$ \\
\hline $\mathrm{Cl}^{-}$ & $8.77 \mathrm{a}$ & $4.14 \mathrm{~b}$ & $14.15 \mathrm{a}$ & $13.35 \mathrm{a}$ & $0.437 \mathrm{a}$ & $0.568 \mathrm{a}$ \\
\hline
\end{tabular}

Values followed by the same letter in the row for 2012 and 2013 considering the different precipitation flows did not differ statistically by Student's $t$-test, at $5 \%$ error probability level.

observed higher input of $\mathrm{K}^{+}$compared to the present study, at $6.14 \mathrm{~kg} \mathrm{ha}^{-1}$ via incident rainfall, $62.1 \mathrm{~kg} \mathrm{ha}^{-1}$ via throughflow, and $2.94 \mathrm{~kg} \mathrm{ha}^{-1}$ via stemflow. These results indicate the influence of precipitation volume on nutrient flow, since there is a lower quantity of ions contributed by wet atmospheric deposition in this study, when compared to Bellot \& Escarre (1991), Calil et al. (2010), and Heartsill-Scalley et al. (2007).

Due to the contribution of rainfall water to nutrient input, fertilization management strategies can be adopted based on studies that evaluate the chemical quality of water and the interaction with the canopy, branches and trunk. Taken together, our findings indicate that fertilizer dosages can be optimized to avoid excess nutrients and reduce costs in forestry operations.

\section{CONCLUSION}

The greatest contribution of nutrients occurred through internal precipitation compared to contribution from incident rainfall and water flow through the trunk. Significant amounts of $\mathrm{K}^{+}, \mathrm{Ca}^{2+}$ and $\mathrm{Cl}^{-}$entered via incident rainfall, and nutrient washing through the canopies (throughfall) is important for the enrichment of the aqueous solution and mineral fertilization of the forest stand.

\section{ACKNOWLEDGEMENTS}

The authors thank StoraEnso for support and availability of the experimental area. Thanks to CNPq for granting scholarship to the first author of this paper.

\section{SUBMISSION STATUS}

Received: 29 may, 2017

Accepted: 13 sep., 2017

\section{CORRESPONDENCE TO}

\section{Grasiele Dick}

Departamento de Ciências Florestais,

Universidade Federal de Santa Maria - UFSM,

Av. Roraima, 1000, Camobi, CEP 97105-900,

Santa Maria, RS, Brasil

e-mail: grasidick@hotmail.com

\section{FINANCIAL SUPPORT}

CNPq and StoraEnso.

\section{REFERENCES}

Alvares CA, Stape JL, Sentelhas PC, Moraes Gonçalves JL, Sparovek G. Köppen's climate classification map for Brazil. Meteorologische Zeitschrift 2014; 22(6): 711-728. http://dx.doi.org/10.1127/0941-2948/2013/0507.

American Public Health Association - APHA, American Water Works Association - AWWA, Water Environment Federation - WEF. Standard methods for the examination of water and wastewater. 19th ed. Washington: Water Pollution Control Federation; 1998.

Armbruster M, Abiy M, Feger K-H. The biogeochemistry of two forested catchments in the Black Forest and the eastern Ore Mountains (Germany). Biogeochemistry 2003; 65(3): 341-368. http://dx.doi.org/10.1023/A:1026250209699.

Ashagrie Y, Zech W. Dynamics of dissolved nutrients in forest floor leachates: comparison of a natural forest 
ecosystem with monoculture of tree species plantations in south-east Ethiopia. Ecohydrology \& Hydrobiology 2010; 10(2-4): 183-190. http://dx.doi.org/10.2478/ v10104-011-0015-6.

Balestrini R, Arisci S, Brizzio MC, Mosello R, Rogora R, Tagliaferri A. Dry deposition of particles and canopy exchange: Comparison of wet, bulk and throughfall deposition at five forest sites in Italy. Atmospheric Environment 2007; 41(4): 745-756. http://dx.doi.org/10.1016/j.atmosenv.2006.09.002.

Balieiro FC, Franco AA, Fontes RLF, Dias LE, Campello EFC, Faria SM. Evaluation of the throughfall and stemflow nutrient contents in mixed and pure plantations of Acacia mangium, Pseudosamenea guachapele and Eucalyptus grandis. Árvore 2007;31(2): 339-346.

Bellot JA, Escarre A. Chemical characteristics and temporal variations of nutrients in throughfall and stemflow of tree species in Mediterranean holm oak forest. Forest Ecology and Management 1991; 41(1-2): 125-135. http://dx.doi. org/10.1016/0378-1127(91)90123-D.

Calil FN, Schumacher MV, Witschoreck R, Lopes VG, Viera $\mathrm{M}$, Liberalesso E. Ion input via rainwater in southwestern region of Rio Grande do Sul, Brazil. Revista Ceres 2010; 16(3): 373-380.

Carnol M, Bazgir M. Nutrient return to the forest floor through litter and throughfall under 7 forest species after conversion from Norway spruce. Forest Ecology and Management 2013; 309: 66-75. http://dx.doi.org/10.1016/j. foreco.2013.04.008.

Chang M. Forest hydrology: an introduction to water and forests. 2nd ed. USA: Taylor \& Francis Group; 2006.

Corrêa RS. Ciclagem de nutrientes em Eucalyptus dunnii estabelecido no bioma Pampa [tese]. Santa Maria: Programa de Pós-graduação em Engenharia Florestal, Universidade Federal de Santa Maria; 2011.

Dezzeo N, Chacón N. Nutrient fluxes in incident rainfall, throughfall, and stemflow in adjacent primary and secondary forests of the Gran Sabana, southern Venezuela. Forest Ecology and Management 2006; 234(1-3): 218-226. http:// dx.doi.org/10.1016/j.foreco.2006.07.003.

Diniz AR, Pereira MG, Balieiro FC, Machado DL, Menezes CEG. Precipitação e aporte de nutrientes em diferentes estádios sucessionais de Floresta Atlântica, Pinheiral RJ. Ciência Florestal 2013; 23(3): 389-399. http://dx.doi. org/10.5902/1980509810550.

Empresa Brasileira de Pesquisa Agropecuária - EMBRAPA. Sistema brasileiro de classificação de solos. 3. ed. Brasília: Embrapa Solos; 2013.

Epstein E, Bloom AJ. Nutrição mineral de plantas: princípios e perspectivas. Londrina: Editora Planta; 2006.

Garten CT Jr, Bondietti EA, Lomax RD. Contribution of foliar leaching and dry deposition to sulfate in net throughfall below deciduous trees. Atmospheric Environment
1988; 22(7): 1425-1432. http://dx.doi.org/10.1016/00046981(88)90167-9.

Heartsill-Scalley T, Scatena FN, Estrada C, McDowell WH, Lugo AE. Disturbance and long-term patterns of rainfall and throughfall nutrient fluxes in a subtropical wet forest in Puerto Rico. Journal of Hydrology 2007; 333(2-4): 472-485. http://dx.doi.org/10.1016/j.jhydrol.2006.09.019.

Laclau J-P, Ranger J, Bouillet J-P, Dieu Nzila J, Deleporte P. Nutrient cycling in a clonal stand of Eucalyptus and an adjacent savanna ecosystem in Congo 3: Chemical composition of rainfall, throughfall and stemflow solutions. Forest Ecology and Management 2003; 176(1-3): 105-119. http://dx.doi.org/10.1016/S0378-1127(02)00280-3.

Laclau J-P, Ranger J, Moraes Gonçalves JL, Maquère V, Krusche AV, M'Bou AT et al. Productivity in Tropical Plantations Biogeochemical cycles of nutrients in tropical Eucalyptus plantations: main features shown by intensive monitoring in Congo and Brazil. Forest Ecology and Management 2010; 259(9): 1771-1785. http://dx.doi. org/10.1016/j.foreco.2009.06.010.

Melo, ABC. Previsão de chuvas acima da normal para o norte do Brasil. Infoclima: Boletim de Informações Climáticas do CPTEC/INPE 2011; 18(11): 1-3.

Paramee S, Chidthaisong A, Towprayoon S, Asnachinda P, Bashkin VN, Tangtham N. Three-year monitoring results of nitrate and ammonium wet deposition in Thailand. Environmental Monitoring and Assessment 2005; 102(13): 27-40. http://dx.doi.org/10.1007/s10661-005-1593-9. PMid:15869176.

Prakasa Rao P, Momin GA, Safai PD, Pillai AG, Khemani LT. Rain water and throughfall chemistry in the Silent Valley forest in south India. Atmospheric Environment 1995; 29(16): 2025-2029. http://dx.doi.org/10.1016/13522310(94)00294-U.

Rodà F, Avila A, Bonilla D. Precipitation, throughfall, soil solution and stream-water chemistry in a holm-oak (Quercus ilex) forest. Journal of Hydrology 1990; 116(1-4): 167-183. http://dx.doi.org/10.1016/0022-1694(90)90121-D.

Schumacher MV, Viera M. Ciclagem de nutrientes em plantações de eucalipto. In: Schumacher MV, Viera M. Silvicultura do eucalipto no Brasil. Santa Maria: UFSM; 2015. p. 273-307.

Shen W, Ren H, Darrel Jenerette G, Hui D, Ren H. Atmospheric deposition and canopy exchange of anions and cations in two plantation forests under acid rain influence. Atmospheric Environment 2013; 64: 242-250. http://dx.doi.org/10.1016/j.atmosenv.2012.10.015.

Silva FAS, Azevedo CAV. Versão do programa computacional ASSISTAT para o sistema operacional Windows. Revista Brasileira de Produtos Agroindustriais 2002; 4(1): 71-78. http://dx.doi.org/10.15871/1517-8595/rbpa.v4n1p71-78.

Singer A, Ganor E, Fried M, Shamay Y. Throughfall deposition of sulfur to a mixed oak and pine forest in 
Israel. Atmospheric Environment 1996; 30(22): 3881-3889. http://dx.doi.org/10.1016/1352-2310(96)00065-9.

Taiz L, Zeiger E. Fisiologia vegetal. 5. ed. Porto Alegre: Artmed; 2013.

Verdum R, Streck EV, Vieira LFS. Degradação dos solos no Rio Grande do Sul. In: Guerra AJT, Jorge MCO. Degradação dos solos no Brasil. Rio de Janeiro: Ed. Bertrand Brasil; 2014. p. 87-126.

Walling DE. Water in the catchment ecosystem. In: Grower AM, editor. Water quality in catchment ecosystem. Chichester: John Wiley \& Sons; 1980. p. 1-47.
Wang MC, Liu CP, Sheu BH. Characterization of organic matter in rainfall, throughfall, stemflow, and streamwater from three subtropical forest ecosystems. Journal of Hydrology (Amsterdam) 2004; 289(1-4): 275-285. http:// dx.doi.org/10.1016/j.jhydrol.2003.11.026.

Waring RH, Schlesinger WH. Forest ecosystems: concepts and management. 3rd ed. New York: Academic Press; 1985.

Whitehead D, Beadle CL. Physiological regulation of productivity and water use in Eucalyptus: a review. Forest Ecology and Management 2004; 193(1-2): 113-140. http:// dx.doi.org/10.1016/j.foreco.2004.01.026. 